\title{
Socio Demographic Study of Gonorrhoea and Syphilis in Two Medical College Hospital and Two Private Chamber in Bangladesh.
}

\author{
Farah $\mathrm{A}^{1}$, Rahman $\mathrm{MH}^{2}$, Rahman $\mathrm{O}^{3}$, Zakir $^{4}$.
}

\begin{abstract}
:
A total 300 (three hundred) Gonorrhea and Syphilis patients were studied in two Medical College Hospital (OPD) and two private Chamber to find out their Socio Demographic Characteristics.

The patients were between 10 to 60 years of age and among them 250 were male and 50 were female. In this study found that the younger age group and unmarried persons are more prevalent. Regarding occupation, service holders are affected more and regarding their socioeconomic condition low and high income group population are also affected more.
\end{abstract}

\section{Introduction}

Treponema pallidum is the microaerophilic spirochete that causes syphilis, a chronic systemic venereal disease with multiple clinical presentation (i.e. the great imitator). Syphilis is characterized by episodes of active disease (primary, secondary, tertiary stages) interrupted by period of latency ${ }^{1,2,3,4}$. Figure 1 shows clinical presentation of a primary syphilis patient.

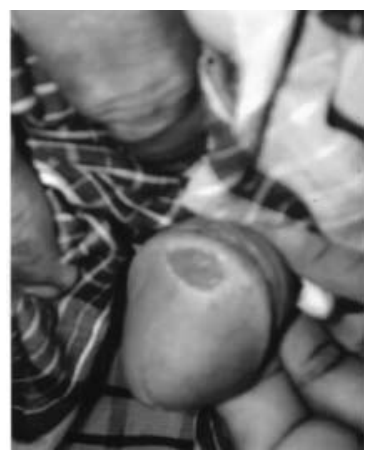

Fig 1: Primary syphilis with a firm, non tender chancre.

Gonorrhoea is a purulent inflammation of the mucous membrane surfaces caused by a sexually transmitted

1. Dr. Abul Farah MBBS, DCM, DDV, MCPS Junior Consultant of Skin \& VD

Sariankandi Upazilla Health Complex, Bogra

2. Corresponding Author :

Dr. Md. Habibur Rahman MBBS, DDV, MPH

Junior Consultant of Skin \& VD

Dhamrai Upazilla Health Complex, Dhaka

3. Dr. Obaidur Rahman MBBS, DDV

Registrar, Departmnet of Skin \& VD

Shaheed Suhrawardi Medical College \& Hospital, Dhaka

4. Dr. Zakir MBBS

Honoray Medical Officer of Department of Skin \& VD Sir Salimullah Medical College \& Mitford Hospital, Dhaka microorganism, Neisseria gonorrhoeae. Virtually any mucous membrane can be infected ${ }^{5,6}$. Figure 2 shows clinical presentation of urethral discharge of a Gonorrhoea patient.

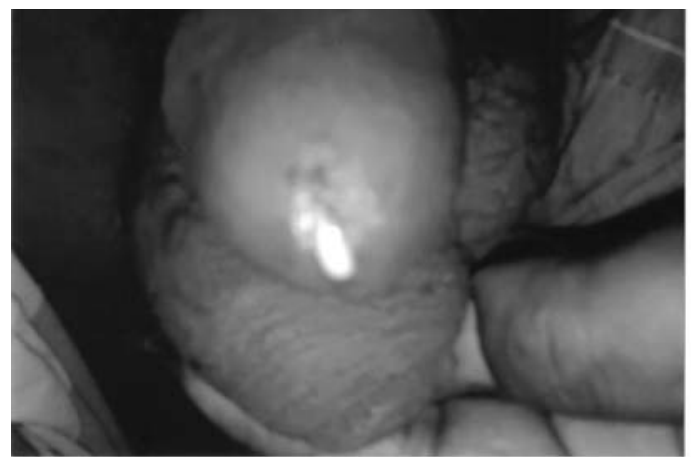

Fig 2: Urethral discharge of a Gonorrhoea

Gonococcal infections following sexual and perinatal transmission are a major source of morbidity worldwide. In the developed world where prophylaxis for neonatal eye infection is standard, the vast majority of infections follow genitourinary mucosal exposure. More serious clinical syndromes may follow, with ascending involvement of the reproductive tract or systemic spread ${ }^{7,8,9}$. Infection is due to N. Gonorrhea, a highly infectious gram-negative diplococcal organism ${ }^{6}$.

Internationally syphilis, remains prevalent in many developing countries and in some areas of North America, Asia and Europe, especially eastern Europe ${ }^{10,11}$.

In some regions of Russia, Such as Tyva and Khakassia in Siberia more than $1 \%$ of the population has syphilis. Primary complications of syphilis in adults include neuro syphilis, cardiovascular syphilis and gumma ${ }^{10,11}$.

Death resulting from syphilis continues to occur. One study found that of 113 recorded deaths resulting from sexually transmitted diseases, 105 were caused by syphilis with cardiovascular and neurosyphilis accounting for the majority of the deaths $s^{12,13}$.

The exchange of antibiotic resistance genes has led to extremely high levels of resistance to beta lactum antibiotic over the last two decades. More recently fluoroquinolone resistance also has been documented on multiple continents $\mathrm{s}^{7,14,15}$. 


\section{Materials \& Methods}

A well planned pretested questionnnaire was made to get necessary information from the patients. From January 2001 to December 31, 2004. Three Hundred patients from OPD and private chamber were studied to see their age, sex, marital status, level of education, occupation, and economic condition.

After diagnosis of the cases by clinical examination and Laboratory investigation, they are divided into several income group like very poor, poor, middle class and rich. According to monthly income of family in taka the patient are categorized into very poor, poor, middle class and rich as (2000/- very poor between 2-5 thousand poor, 5-10 thousand middle class, above 10,000/- rich respectively. Regarding demography only two components considered here like level of education and marital status.

\section{Results}

Table 1 one shows out of 300 patients , $200(66.66 \%)$ were in the age group 16-25 years, $40(13.34 \%)$ were in $36-45$ year, $30(10 \%)$ were above 45 years, $28(9.34 \%)$ were in $26-$ 35 years and only $02(0.66 \%)$ were in the age group of 1015 years.

Table-1: Age and sex distribution of the patients:

\begin{tabular}{|c|c|c|c|}
\hline \multirow{2}{*}{$\begin{array}{l}\text { Age Group } \\
\text { in years }\end{array}$} & \multicolumn{2}{|c|}{ Number of patients } & \multirow[t]{2}{*}{ Total } \\
\hline & Male (\%) & Female (\%) & \\
\hline 10-15 Years & $2(66 \%)$ & $0 \%$ & $02(0.66 \%)$ \\
\hline 16-25 Years & $150(50 \%)$ & $50(16.66 \%)$ & $200(66.66 \%)$ \\
\hline 26-35 Years & $28(9.34 \%)$ & $0(0 \%)$ & $28(9.34 \%)$ \\
\hline $36-45$ Years & $40(13.34 \%)$ & $0(0 \%)$ & $40(13.34 \%)$ \\
\hline Above 45 Years & $30(10 \%)$ & $0(0 \%)$ & $30(10 \%)$ \\
\hline Total & $250(83.34 \%)$ & $50(16.66 \%)$ & 300 \\
\hline
\end{tabular}

Table 2 shows regarding level of education $100(33.33 \%)$ patients completed secondary, $50(16.67 \%)$ high school another $50(16.67 \%)$ Primary School and 75 (25\%) Patients had a degree and above education. Only $25(8.33 \%)$ had no literacy. $175(58.33 \%)$ were unmarried and 125 (41.67\%) married (Table 3).

Table-2: Distribution of patient by level of education (LOE)

\begin{tabular}{lcc}
\hline LOE & Number & \% \\
\hline Illiterate & 25 & 8.33 \\
Primary & 50 & 16.67 \\
Secondary & 100 & 33.33 \\
High School & 50 & 16.67 \\
Degree and Above & 75 & 25.00 \\
Total & 300 & $100 \%$ \\
\hline
\end{tabular}

Table-3: Distribution of patients by marital status

\begin{tabular}{lcc}
\hline Marital status & Number of patient & $\%$ \\
\hline Unmarried & 175 & 58.33 \\
Married & 125 & 41.67 \\
Total .4 & 300 & $100 \%$ \\
\hline
\end{tabular}

Table 4 shows half of the patients $(50 \%)$ were of poor status, $100(33.33 \%)$ rich and the rest $50(16.67 \%)$ patients fell in the middle class.

Table-4: Distribution of patients by economic status

\begin{tabular}{lcc}
\hline Economic status & Number of patient & $\%$ \\
\hline Poor & 150 & 50 \\
Middle class & 50 & 16.67 \\
Rich & 100 & 33.33 \\
Total & 300 & $100 \%$ \\
\hline
\end{tabular}

Table 5 shows nearly half $(46.67 \%)$ of the patient were service holder, one third $33.33 \%$ ) were small traders and the rest were student, and day labourers.

Table-5: Distribution of patients by occupation.

\begin{tabular}{lcc}
\hline Occupation & Number of patients & \% \\
\hline Service & 140 & 46.67 \\
Student & 35 & 11.67 \\
Day Laborers & 25 & 8.33 \\
Traders & 100 & 33.33 \\
Total & 300 & $100 \%$ \\
\hline
\end{tabular}

\section{Discussion}

This is a descriptive type of epidemiological study, carried out in the outpatient dept. of two medical college hospitals and two private chambers of Dhaka city during the period of January 2001 to 31, December 2004. A Total of 300 patients of syphilis and Gonorrhoea were studied to see their socio demographic characteristics.

Syphilis and Gonorrhoea are mostly $(66.66 \%)$ prevalent among the youngs (16-25 years) and less (9.34\%) among the patients of age group 26-35 years. Exceptionally only two patients were found amongst the age group 10-15 years. Findings are consistant with Engelkens $\mathrm{HJ}^{16}$, Wicher ${ }^{17}$ \& Da Ros $\mathrm{CT}^{18}$.

The patients having secondary level of education are more in number and least among the illiterate $(8.33 \%)$. One fourth of the patients $(25 \%)$ had degree and above level of education. So Education is not only the factor in causation of the diseases.

Unmarried patients were more $(58.33 \%)$ than the married $(41.67 \%)$. Half $(50 \%)$ of the patients were of poor socioeconomic status and of middle class has the least number of patients. Highest number $(46.67 \%)$ of patients are service holder and the students are least in number of the affected patients.

This study concludes that the sexually transmitted diseases are found more amongst the younger age group, service holders, unmarried and how \& high income group of people. The results found in this study are consistent with the previous studies. It recommends further study to know the altered scenario if any, with the change of culture and socioeconomic stratification. 


\section{References}

1. Garnett GP, Aral So, Hoyle DV. The natural history of syphilis. Implications for the transmission dynamics and control of infection. Sex tra.nsm dis. 1997;24:185200[Medline].

2. Luke hart SA, Holmes KK. Syphilis In: Fauci AS, ed. Harrison's Principles of Internal Medicine. 14th ed. New York: McGraw-Hill; 1998:1023-33.

3. Nakashima AK, Rolfs RT, Flock ML. Epidemiology of syphilis in the United Staes, 1941-1993. Sex Transm Dis 1996;23:16-23[Medline]

4. Goldman L, Ausiello D. Cecil Medicine. Chapter-340. 3dr Edition, Saundrs Elsevier, 2008.

5. Cox Dl, Chang P, Me Dowall AW, Radolf JD. The outer membrane, not a coat of host proteins, limits antigen city of virulent Treponema palladium. Infect Immune 1992;60:1076 83[Medline].

6. Wolff, Klaus. Fitzpatrick's Dermatology in General Medicine. Seventh edition. Mc Graw Hill Medical. 2008;2:11993-6

7. $\mathrm{CDC}$, guidelines for treatment of sexually transmitted diseases. MMWR Morb Mortal Wkly Rep 1998;47:4969 [Medline].

8. Litt IF: Sexually transmitted diseases. In: Nelson's Textbook of Pediatrics. Philadelphia; 1996:552-553.

9. Ross JD: Systemic gonococcal infection. Genitourin Med 1996;72: 404-7 [Medline].
10. Kovbian VA, Gomberg MA, Prokhorenkov VI: Syphilitic vignettes from Russia. Dermatol Clin 1998;16:687-90 [Medline].

11. Corbie-Smith G. The continuing legacy of the Tuskegee Syphilis Study: considerations for clinical investigation. Am J Med sci 1999;317:5-8 [Medline].

12. Destructive bone disease in early syphilis. JAMA 19766;236:2646-83[Medline]

13. Fitzgerald TJ: the Thl/Th2 like switch in syphilitic infection: is it detrimental? Infect Immun 1992;60:3475-9[Medline].

14. Young H. Syphilis. Serology. Demerol Clin 1998 Oct; 16:691-8

15. Knapp JS, Fox K.K, Trees DL, Whittngton WL. Fluoroquinolone resistance in Neisseria gonorrhoeae. In: Emerging Infectious Diseases. 1997:3:33-9.

16. Engelkens HJ et al: Endemic treponematoses, Part II : Pinta and endemic syphilis [review]. Int. J. dermatol 30;231:1991.

17. Wicher $\mathrm{K}$ et al : Treponema Pallidum subsp. Pertenue displays pathogenic properties different from those of T.pallidum subsp. Pallidum. Infect Immun 2000;68:3219.

18. Da Ros CT, Schmitt Cda S. Golbal epidemiology of sexually transmitted diseases. Asian $\mathrm{J}$ Androl. 2008;10:110-4. 